\title{
Spectroscopic analysis of organic materials susceptible to transformation processes
}

\section{Análisis espectroscópico de materiales orgánicos susceptibles a procesos de transformación}

MORENO-MARTINEZ, Beatríz Eugenia ${ }^{1} \dagger^{*}$, RAMIREZ-SALAS, Virginia ${ }^{2}, Z_{\text {ZAVALA-ARCE, Rosa }}$ Elvira $^{3}$ and GONZALEZ-SANCHEZ, Cielo Vanessa ${ }^{1}$

Instituto Tecnológico de Nuevo León / Tecnológico Nacional de México, Departamento de Ingeniería Industrial Instituto Tecnológico de Ciudad Madero/Tecnológico Nacional de México, Departamento de Ingeniería Química y Bioquímica

Instituto Tecnológico de Toluca/ Tecnológico Nacional de México, Departamento de Posgrado e Investigación

ID $1^{\text {st }}$ Author: Beatríz Eugenia, Moreno-Martínez / ORC ID: 0000-0002-8343-0895, CVU CONACYT ID: 162379

ID $1{ }^{\text {st }}$ Coauthor: Virginia, Ramírez-Salas / ORC ID: 0000-0002-0548-8653, CVU CONACYT ID: 173197

ID $2^{\text {nd }}$ Coauthor: Rosa Elvira, Zavala-Arce / ORC ID: 0000-0002-8056-5284, CVU CONACYT ID: 215500

ID $3^{\text {rd }}$ Coauthor: Cielo Vanessa, Gonzalez-Sanchez

DOI: $10.35429 / E J B .2020 .13 .7 .1 .6$

Received July 18, 2020; Accepted November 30, 2020

\begin{abstract}
Carry out a spectroscopic study of various materials of organic origin, specifically residues from various processes, both biological and agro-industrial, in order to study their structural characteristics in their main functional groups, since their nature can determine the viability of a process of recycling to obtain new products. Some of the organic materials studied were of great importance because these materials can be susceptible to transformation through various processes such as thermochemical, biological, and biochemical transformation. Leaf samples from the Moringa plant (Moringa Oleifera), orange peels (Citrus sinensis), as well as leachate from the vermicomposting process of the Californian red worm (Eisenia foetida) were analyzed. The results obtained indicate a different composition, but in turn, show similarity in some specific bands, such as carboxylic acids, OH groups, methyl groups, as well as some aromatic groups in the case of citrus fruits. The importance of this research lies in the fact in the study of the transformation processes of these wastes, for future applications.
\end{abstract}

Thermochemical transformation, Spectroscopy, Waste

\begin{abstract}
Resumen
Realizar un estudio espectroscópico a diversos materiales de origen orgánico, específicamente residuos de diversos procesos, tanto biológicos como agroindustriales, con la finalidad de estudiar sus características estructurales en sus grupos funcionales principales, ya que la naturaleza de ellos puede determinar la viabilidad de un proceso de reciclaje para la obtención de nuevos productos. Algunos de los materiales orgánicos estudiados fueron de suma importancia, debido a que estos materiales pueden ser susceptibles de transformación mediante diversos procesos tales como transformación termoquímica, biológica, y bioquímica. Se analizaron muestras de hojas de la planta de Moringa (Moringa Oleifera), cáscaras de naranja (Citrus sinensis), así como lixiviado del proceso de vermicompostaje de la Lombriz roja californiana (Eisenia foetida). Los resultados obtenidos señalan una composición diferente, pero a su vez, muestran similitud en algunas bandas específicas, tales como ácidos carboxílicos, grupos $\mathrm{OH}$, grupos metílicos, así como algunos grupos aromáticos en el caso de los cítricos. La importancia de esta investigación, radica en la viabilidad de poder $\mathrm{n}$ el hecho en el estudio de los procesos de transformación de estos residuos, para futuras aplicaciones.
\end{abstract}

Transformación termoquímica, Espectroscopia, Residuos

Citation: MORENO-MARTINEZ, Beatríz Eugenia, RAMIREZ-SALAS, Virginia, ZAVALA-ARCE, Rosa Elvira and GONZALEZ-SANCHEZ, Cielo Vanessa. Spectroscopic analysis of organic materials susceptible to transformation processes. ECORFAN Journal-Bolivia. 2020. 7-13: 1-6

\footnotetext{
* Correspondence to Author (email: beatrizeugenia_m_mtz@yahoo.com.mx)

$\dagger$ Researcher contributing first author.
} 


\section{Introduction}

Biomass is a removable resource that currently has multiple applications. There are numerous biomass classifications, but the most accepted, and based on their composition, origin, and state are the following types: a) Depending on their composition: they can be oleoginous, lignocellulosic, b) depending on their origin, it can be natural, residual or from energy crops and c) depending on its state, it can be solid, liquid or gaseous. In this research work, three types of organic materials susceptible to transformation were analyzed, whether biological, thermochemical and chemical, these are: orange peels, moringa leaves and worm castings in their solid and liquid form. [1]

From various thermal, chemical and / or biological processes, biomass of lignocellulosic origin can be transformed into: a) heat energy, b) electrical energy, c) biogas, d) bioethanol, e) biodiesel, f) bioturbosin, g ) chemicals with different levels of oxygenation. In particular, the pyrolysis process of lignocellulosic biomass generates three products: i) synthesis gas, ii) bio-oil and iii) biochar. Biochar is an organic material with a high carbon content and that is classified as a multifunctional material with various applications, among which is its use as an organic soil additive. In this section. [3]

The residual organic matter plays an important potato in aspects such as recycling, if the residual organic matter is transformed, the polluting agents are reduced. The use of organic waste would solve many environmental and social problems, because its transformation would generate jobs.

Currently, in terms of waste utilization through the vermicomposting process, more than half of the organic matter in municipal waste is wasted and goes to landfill. Only $19 \%$ of the part that receives some treatment is collected separately and therefore produces a quality compost. The production of earthworm humus is obtained by the well-known vermiculture technique that allows to take advantage of and transform almost all organic solid waste derived from agricultural, livestock, agro-industrial and urban activities. They are also known as: vermicompost, vermicompost, and so on.
It should be noted that the cultivation of worms requires very low costs and that the fertilizer produced by these has been increasing in its use, as it is a source of slow-release nutrients in the soil, which implies a considerable economy of agricultural fertilizers and of labor, guaranteeing the necessary balance in the phases of strong demand of the plant.

The objective of this research was to collect the different types of biomass, such as moringa leaves, which may have important functional groups that make it a possible coagulant agent to eliminate particles suspended in water, lignocellulosic residues such as orange peels. in order to obtain fibers and worm humus, as well as to carry out an Infrared Analysis by Fourier Transform (FTIR) study in order to consider possible subsequent uses by virtue of their main functional groups. Figure 1 shows the different chemical structures that moringa oleifera presents. [4]

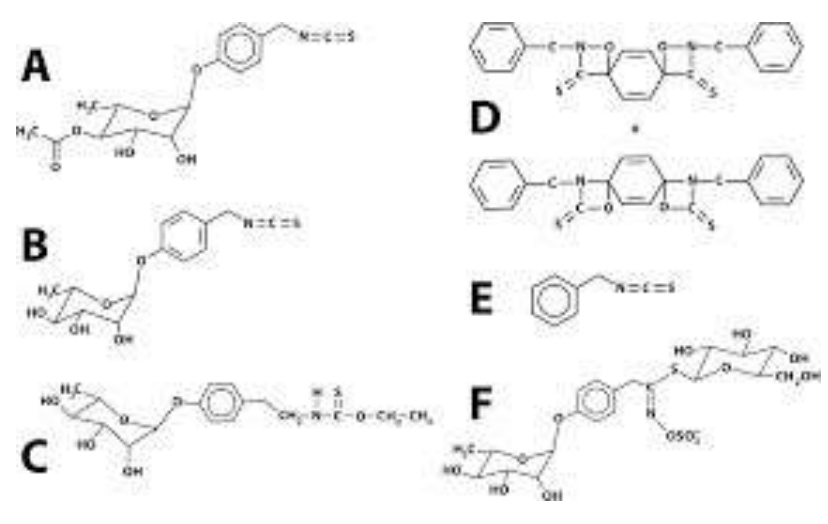

Figure 1 Possible structures of Moringa Oleifera. Mexican Journal of Biodiversity 82: 1071-1082, 2011

Figure 2 shows the possible chemical structure of lignin, an insoluble material in the orange peel.

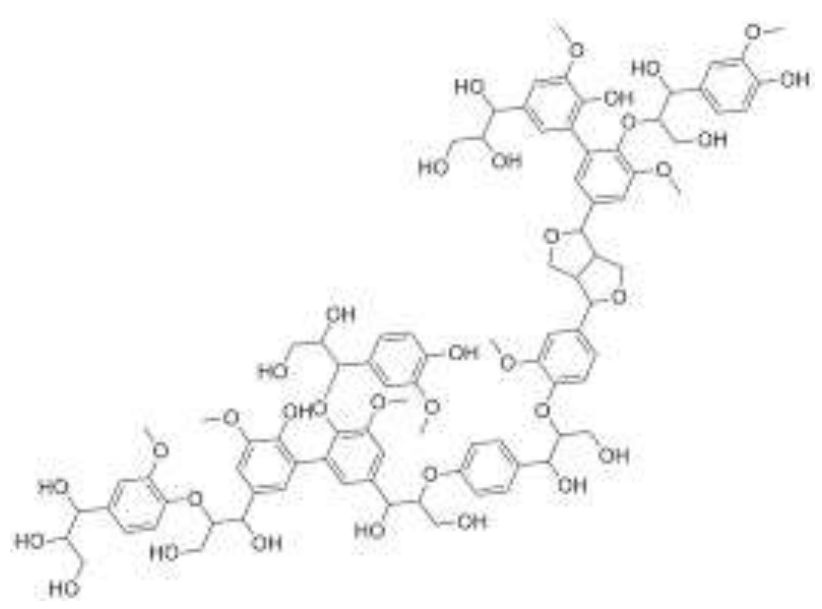

Figure 2 Possible structure of Lignin

Yair Santiago Saenz 
Moringa oleifera seeds have been shown to contain significant amounts of polar amino acids, with a net positive and negative charge, which could interact with the colloidal particles responsible for turbidity and color during the water clarification process, contributing to their elimination. , [2] Moringa oleifera is a crop native to northern India, currently abundant throughout the tropics. The variety of names in both English and vernacular illustrates the many uses assigned to the tree and its products.

In the case of the vermicompost process, the aim is to evaluate the contribution of nitrogen $(\mathrm{N})$ and other nutrients in the compost tea to produce beans in a hydroponic NFT process, using the compost tea as a hydroponic solution.

\section{Methodology}

The orange peels were obtained from the Mexican Citrus Company, located in the Municipality of Montemorelos, Nuevo León, as well as from the Don Luis juicer, located in the Central de Abasto, Guadalupe municipality, Nuevo León. We worked with orange peels of the Mars variety, from which the bagasse was removed and only the flavedo and albedo of the orange were worked. It was subjected to a bleaching process and the essential oil was subsequently extracted and thermochemically transformed into charcoal and subsequently a pyrolysis process was carried out at $370^{\circ} \mathrm{C}$. These materials were characterized in a Fourier Transform Infrared Spectroscopy, FTIR equipment. The Fourier Transform Infrared Spectroscopy analysis was carried out on a Nicolet iS10 Thermo Scientific brand with universal ATR iTR sampling accessory, the analysis was carried out at 32 scans, the sample was previously dried at a temperature of $70^{\circ} \mathrm{C}$ for a time of 24 hours.

Moringa Oleifera seeds have a high content of vegetable oil in their composition, which must be extracted in order to take advantage of the protein that the seeds contain, which is important during the water coagulation process. For the extraction of the oil from the Moringa Oleifera seeds, it was necessary in the first stage to submit them to a manual dehulling process, thus eliminating this element which is not necessary during the coagulant preparation process;
Once the seeds were dehulled, they were introduced and crushed inside a porcelain capsule with the help of a mortar, thus reducing their size and making them easier to handle during the oil extraction process. For the oil extraction process from Moringa Oleifera seeds, a solvent extractor equipment was used. In Figure 3 a part of the proposed methodology for the pre-treatment and the obtaining process is observed. The Fourier Transform Infrared Spectroscopy analysis was carried out on a Nicolet iS10 Thermo Scientific brand with universal ATR iTR sampling accessory, the analysis was carried out at 32 scans, the sample was previously dried at a temperature of $85^{\circ} \mathrm{C}$ for a time of 24 hours.

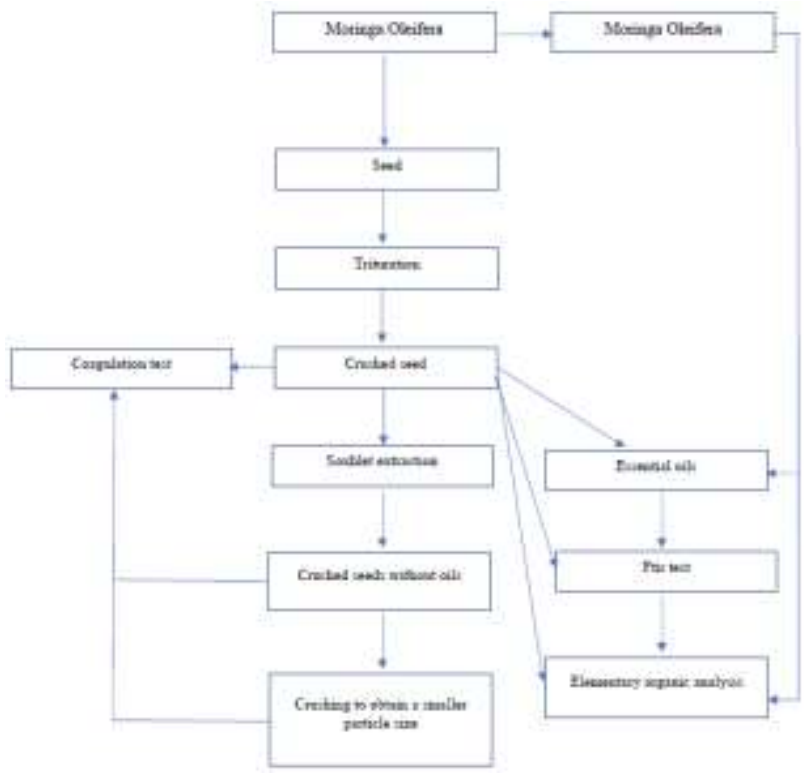

Figure 3 Methodology used for the processing of moringa fiber as a possible coagulant of impurities in water

In the study of vermicompost, organic household waste was collected in order to subject it to a biological process through degradation using the Californian red worm, (Eisenia foetida), the vermicompost was monitored under the following variables: degree of darkness in the substrate, $\mathrm{pH}$ level, and moisture percentage, as well as its Nitrogen content as a possible nutritive agent. The data obtained by FT-IR and the $\mathrm{N}$ content indicate that this leachate is highly nutritious and can replace an inorganic nutrient solution. The corresponding chemical analyzes were carried out, in order to qualitatively detect the Nitrogen, phosphorus, potassium and $\mathrm{pH}$ values using a soil analysis kit, model HI3896 brand Hanna Instruments, the leachate obtained was characterized physicochemically by means of an Infrared Spectroscopy equipment.

MORENO-MARTINEZ, Beatríz Eugenia, RAMIREZ-SALAS, Virginia, ZAVALA-ARCE, Rosa Elvira and GONZALEZ-SANCHEZ, Cielo Vanessa. Spectroscopic analysis of organic materials susceptible to transformation processes. ECORFAN Journal-Bolivia. 2020 
By Fourier Transform, ThermoScientific Nicolet iS10 brand FTIR with diamond tip ATR accessory. The degree of humidity was detected by the method proposed by Ferruzi (1986), which consists of compressing a handful of the substrate material with the hand and checking that, being completely wet, it does not release water.

\section{Results}

In the infrared spectrum of Figure 4, it is observed how the -OH groups are present in the $3320 \mathrm{~cm}^{-1}$ band, these functional groups are characteristic of the cellulose present in the plant material, as well as of the molecular moisture present in the sample, in the same way the methyl groups $-\mathrm{CH}_{3}$ and methylenes $-\mathrm{CH}_{2}$ that correspond to the groups located in the band $2923 \mathrm{~cm}^{-1}$ characteristic of the carbon chain of the polysaccharides present, as well as the many components of the shell, such as limonene, which is a terpene. In the $1607 \mathrm{~cm}^{-1}$ absorption band, the characteristic band of the carbonyl group is observed, typical of the carboxylic acid groups, specifically, of the citric acid contained in the composition of the orange peel, which is a tricarboxylic acid $\mathrm{COOH}$, located on the $1729 \mathrm{~cm}^{-1}$ band.

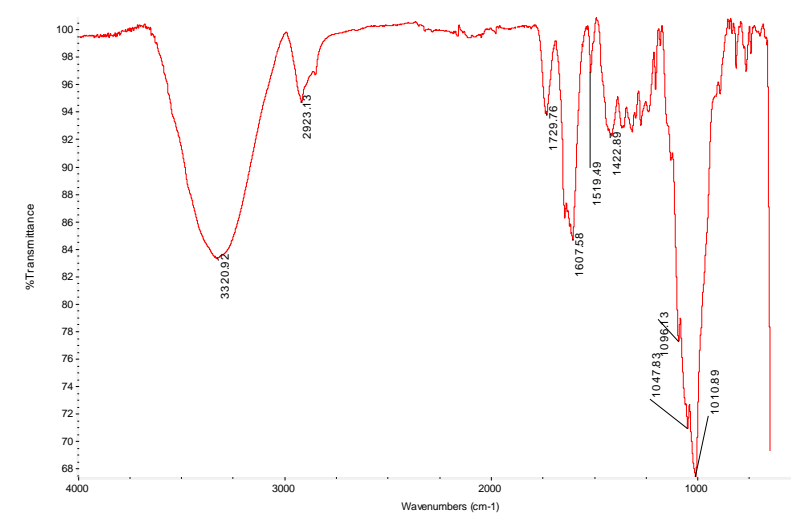

Figure 4 Fourier transform infrared spectrum of the orange peel sample

Figure 5 shows the Fourier transform infrared spectrum of the Moringa sample [5] processed, according to the methodology cited in Figure 3. The active functional groups present in the moringa powder were determined using the technique by FT-IR.

The results obtained by means of the FTIR technique indicate similar profiles with characteristic bands of lignocellulosic materials.

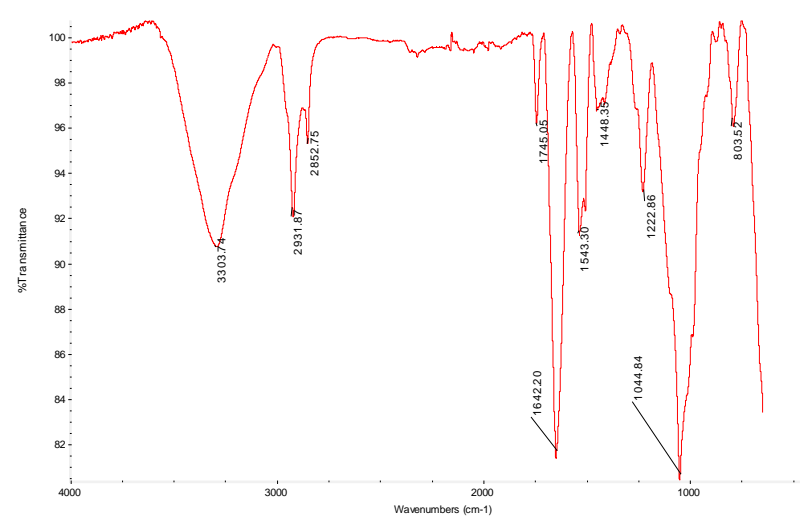

Figure 5 Fourier transform infrared spectrum of the moringa oleifera sample

Based on the assignments presented in the literature, bands located around $3303 \mathrm{~cm}-1$ are observed, which can be attributed to the stretching vibrations of $\mathrm{O}-\mathrm{H}$ groups present in proteins, fatty acids, carbohydrates (cellulose and hemicellulose) and lignin. A contribution in this region can also be inferred from $\mathrm{N}-\mathrm{H}$ and $\mathrm{C}-\mathrm{H}$ groups that also absorb in this infrared region and that are overlapping with the $\mathrm{O}-\mathrm{H}$ group.

The peaks at $2931 \mathrm{~cm}-1$ and $2852 \mathrm{~cm}-1$ assigned to the symmetric and asymmetric stretching of $\mathrm{C}-\mathrm{H}$ groups corresponding to the $\mathrm{CH}_{2}$ groups present in fatty acids. An intense band is observed at $1642 \mathrm{~cm}^{-1}$ characteristic of the vibrations of the carbonyl group $(\mathrm{C}=\mathrm{O})$. A small band observed at $1735 \mathrm{~cm}^{-1}$ suggests that the carbonyl group may be present in different structures. In this case, the band at $1745 \mathrm{~cm}^{-1}$ can be associated with fatty acids and the band at $1642 \mathrm{~cm}^{-1}$ with the amide group in proteins. A small interaction is also observed around $1543 \mathrm{~cm}-1$ which can be assigned to stretching of C-N bonds and / or N-H deformation. Likewise, an intense band around $1448 \mathrm{~cm}^{-1}$ stands out, attributed to the N-H bonds present in the amides.

The presence of these bands confirms the presence of protein in the moringa seeds studied. This protein is responsible for the coagulation of the suspended particles present in the water. Regarding the vermicomposting process, the following results were obtained:

Next, the results obtained from the chemical characterization of the californian red worm leachate are shown, in Table 1 some of the qualitatively obtained values of the earthworm leachate can be observed. 


\begin{tabular}{|l|l|l|}
\hline \multicolumn{1}{|c}{ No. } & \multicolumn{1}{c|}{ Analysis Type } & $70-80 \%$ \\
\hline 1 & Worm reservoir moisture & High level \\
\hline 2 & Nitrogen content in solid humus & Medium level \\
\hline 3 & Potassium content in solid humus & Low level \\
\hline 4 & Phosphorus content in solid humus & 8.0 \\
\hline 5 & Hydrogen potential in leachate & 8.0 a 11.0 \\
\hline 6 & C / N ratio in leachate & $20^{\circ} \mathrm{C}$ \\
\hline 7 & $\begin{array}{l}\text { Average temperature of the worm } \\
\text { reservoir }\end{array}$ & $5.0 \mathrm{mg} / \mathrm{L}$ \\
\hline 8 & Nitrite NO2 content in leachate & $160 \mathrm{mg} / \mathrm{L}$ \\
\hline 9 & Nitrate NO3 content in leachate \\
\hline
\end{tabular}

Table 1 Quantitative and qualitative results of earthworm leachate and vermicompost

Next, the infrared spectrum performed on the worm leachate sample is described, which presented a dark coloration, without odor, without residues because it was previously filtered and oxygenated. Figure 6 shows the bands corresponding to the $\mathrm{OH}$ groups in 3345 $\mathrm{cm}-1$ well defined and corresponding to the bands that overlap the $\mathrm{OH}$ bands of the functional groups such as .C-H-stretching and combinations of the nutrients. The leachate sample contains to a large extent fulvic and humic acid, its main functional groups are: $\mathrm{OH}$, $\mathrm{C}=\mathrm{O}$, which is observed in the $1625 \mathrm{~cm}^{-1}$ band

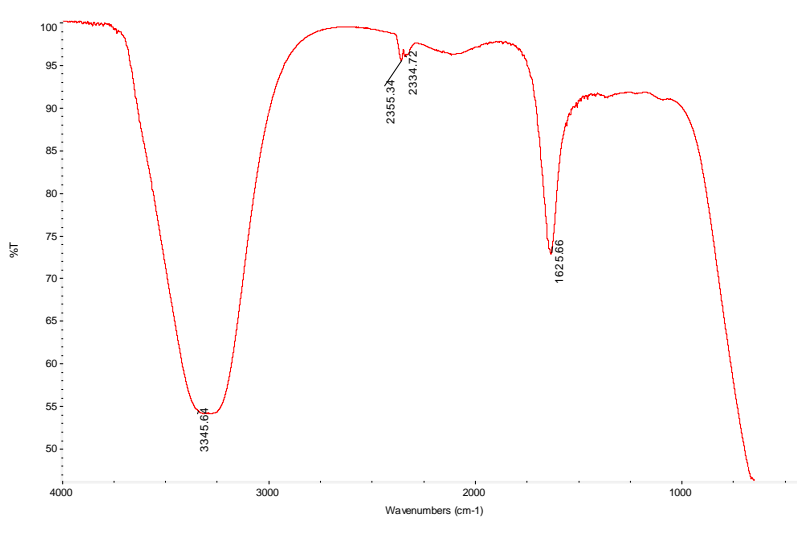

Figure 6 Fourier transform infrared spectrum of the leachate or compost tea sample

\section{Conclusions}

The presence of organic waste in landfills has very negative effects on the environment, such as emissions of methane, which is a powerful greenhouse gas, contamination of aquifers by leaching and odors in nearby inhabited areas.

The transformation of organic waste, by the most convenient method is important, since this notably reduces pollution by solid waste in the open.
The residual agro-industrial biomass (orange peels) as well as the forest biomass (moringa leaves), and products obtained from biological processes can be used for material or energy uses, seeking an adequate balance between them. In addition to producing paper or wood, biomass can be used to replace nonrenewable materials. This can help decarbonize the economy, reducing dependence on fossil fuels, improving security of supply and avoiding climate change.

Green chemistry is emerging as an emerging sector that is reaching a growing share in the most dynamic economies.

The liquid extract of earthworm humus is a biostimulant that has been making its way into the national agricultural market for more than a decade. It has been proven that it is an efficient product in the delivery of organic matter to the soil and nutrients to the plants through the irrigation system, with benefits such as the adequate distribution of nutrients in the field and the stimulation of root and aerial development of crops.

\section{References}

[1] Tuck, C. O., Pérez, E., Horváth, I. T., Sheldon, R. A., Poliakoff, M. Valorization of Biomass: Deriving More Value from Waste. Science. 337, 695-699 (2012).

[2] Soriani M. Eficiência da Moringa Oleifera como Coagulante Natural em Solução Salina para Água de Abastecimento. Universidade Tecnológica Federal Do Paraná Curso De Engenharia Ambiental. Trabalho De Conclusão De Curso. Londrina, 2015.

[3] Agauskas, A. J., et al. Lignin Valorization: Improving Lignin Processing in the Biorefinery. Science. 344, 709-719 (2014).

[4] Sun, Z., Fridrich, B., de Santi, A., Elangovan, S., Barta, K. Bright Side of Lignin Depolymerization: Toward New Platform Chemicals. Chemical Reviews. 118, (2), 614678 (2018).

[5] Santos AM et al. Estudo da coagulação química do efluente da indústria de laticínios utilizando a moringa como agente coagulante. Anais. In: Encontro Nacional De Moringa, 2009, Aracajú. 
[6] Schutyser, W., Renders, T., Van den Bosch, S., Koelewijn, S. F., Beckham, G. T., Sels, B. F. Chemicals from lignin: an interplay of lignocellulose fractionation, depolymerization, and upgrading. Chemical Society Reviews.47, (3), 852-908 (2018). 